\title{
Adsorption of cadmium and copper in representative soils of Eastern Amazonia, Brazil
}

\section{Adsorção de cádmio e cobre em solos representativos da Amazônia Oriental, Brasil}

\author{
Deyvison Andrey Medrado Gonçalves ${ }^{1}$; Gilson Sergio Bastos de Matos²; \\ Antonio Rodrigues Fernandes ${ }^{3 *}$; Katiane Raquel Mendes Barros ${ }^{4}$; \\ Danielle do Socorro Nunes Campinas ${ }^{5}$; Cristine Bastos do Amarante ${ }^{6}$
}

\begin{abstract}
Studies of heavy metals adsorption in soil play a key role in predicting environmental susceptibility to contamination by toxic elements. The objective of this study was to evaluate cadmium $(\mathrm{Cd})$ and copper $(\mathrm{Cu})$ adsorption in surface and subsurface soil. Samples of six soils: Xanthic Hapludox (XH1 and XH2), Typic Hapludox (TH), Typic Rhodudalf (TR), Typic Fluvaquent (TF), and Amazonian dark earths (ADE) from Eastern Amazonian, Brazil. The soils were selected for chemical, physical and mineralogical characterization and to determine the adsorption by Langmuir and Freundlich isotherms. All soils characterized as kaolinitic, and among them, $\mathrm{XH} 1$ and $\mathrm{XH} 2$ showed the lowest fertility. The Langmuir and Freundlich isotherms revealed a higher $\mathrm{Cu}$ ( $\mathrm{H}$ curve) than $\mathrm{Cd}$ ( $\mathrm{L}$ curve) adsorption. Parameters of Langmuir and Freundlich isotherms indicate that soils TR, TF and ADE has the greatest capacity and affinity for metal adsorption. Correlation between the curve adsorption parameters and the soil attributes indicates that the $\mathrm{pH}, \mathrm{CEC}, \mathrm{OM}$ and $\mathrm{MnO}$ variables had the best influence on metal retention. The Langmuir and Freundlich isotherms satisfactorily described $\mathrm{Cu}$ and $\mathrm{Cd}$ soil adsorption, where TR, TF and ADE has a lower vulnerability to metal input to the environment. Besides the $\mathrm{pH}$, $\mathrm{CEC}$ and $\mathrm{OM}$ the $\mathrm{MnO}$ had a significant effect on $\mathrm{Cu}$ and $\mathrm{Cd}$ adsorption in Amazon soils.

Key words: Amazonian dark earths. Environmental management. Heavy metals. Isotherm. Soil pollution.
\end{abstract}

\section{Resumo}

Estudos de adsorção de metais pesados no solo desempenham um papel chave em prever a susceptibilidade à contaminação do ambiente por elementos tóxicos. O objetivo foi avaliar a adsorção de cádmio $(\mathrm{Cd}) \mathrm{e}$ cobre $(\mathrm{Cu})$ na superfície e subsuperfície de seis solos Amazônicos: Latossolo Amarelo (XH1 e XH2), Latossolo Vermelho (TH), Nitossolo Vermelho (TR), Gleissolo Háplico (TF) e Latossolo Amarelo Terra Preta de Índio (ADE) da Amazônia Oriental. Os solos foram selecionados para caracterização química, física, mineralógica e determinação da capacidade máxima de adsorção pelas isotermas de Langmuir e Freundlich. Todos os solos foram caracterizados como cauliníticos, e entre eles, XH1 e XH2 apresentaram menor fertilidade. As isotermas de Langmuir e Freundlich revelaram adsorção superior

\footnotetext{
${ }^{1}$ Eng $^{\circ}$ Agr $^{\circ}$ e Florestal, Discente do Curso de Doutorado em Agronomia, Universidade Federal Rural da Amazônia, UFRA, Belém, PA, Brasil. Bolsista Capes. E-mail: deyvison.medrado@ufra.edu.br

${ }^{2}$ Eng $^{\circ}$ Agro $^{\circ}$, Prof. Dr., UFRA, Tomé-Açu, PA, Brasil. E-mail: gilsonsbm@yahoo.com.br

${ }^{3}$ Eng $^{\circ}$ Agr $^{\circ}$, Prof. Titular, UFRA, Belém, PA, Brasil. E-mail: antonio.fernandes@ufra.edu.br

${ }^{4}$ Eng $^{\mathrm{o}} \mathrm{Agr}^{\mathrm{O}}$, Discente do Curso de Doutorado em Agronomia, UFRA, Belém, PA, Brasil. E-mail: anne_barros22@yahoo.com.br

${ }^{5}$ Me. em Agronomia, Belém, PA, Brasil. E-mail: daniellecampinas@yahoo.com.br

${ }^{6}$ Enga Química, Pesquisadora, Museu Paraense Emílio Goeldi, MPEG, Belém, PA, Brasil. E-mail: cbamarante@museu-goeldi.br

${ }^{*}$ Author for correspondence
} 
de $\mathrm{Cu}$ (curva $\mathrm{H}$ ) em relação ao Cd (L curva). Os parâmetros de Langmuir e Freundlich indicam que os solos TR, TF e ADE tem a maior capacidade e afinidade para adsorção de metais. A correlação entre os parâmetros da curva de adsorção e os atributos do solo indica que o $\mathrm{PH}$, capacidade de troca de cátion (CTC), matéria orgânica (MO) e óxido de manganês $(\mathrm{MnO})$ tiveram influência sobre a retenção dos metais. As isotermas de Langmuir e Freundlich descreveram satisfatoriamente a adsorção de $\mathrm{Cu}$ e $\mathrm{Cd}$ no solo, onde TR, TF e $\mathrm{ADE}$ tem uma menor vulnerabilidade à entrada de metais para o meio ambiente. Além do $\mathrm{pH}, \mathrm{CTC}$ e $\mathrm{MO}$, o $\mathrm{MnO}$ teve um efeito significativo na adsorção de $\mathrm{Cu}$ e $\mathrm{Cd}$ em solos amazônicos.

Palavras-chave: Isoterma. Manejo ambiental. Metais pesados. Poluição do solo. Terra preta do índio.

\section{Introduction}

The Amazon region is the last agricultural frontier and mineral province in Brazil, but most croplands in this region are acidic and have low capacity cation exchange, these attributes contribute to the naturally low fertility of these areas (SILVA et al., 2013), which leads to exposure of their environments to various materials of pollution potential. In this regard, the entry of heavy metals in the soil can occur with the use of fertilizers, liming material, manure, sewage sludge and industrial emissions (SPARKS, 2002), as well as residues of the mining activities (CASSELLA et al., 2006).

The study of adsorption of metals in the soil is an important evaluation tool of the polluting potential of these elements (DÈRE et al., 2006). To describe the metal adsorption forms in the soil, physicochemistry models are utilized, and several equations are proposed to fit the equilibrium solution data (MOREIRA; ALLEONI, 2010). Among these models are the Langmuir and Freundlich curves, which are simple and provide consistent information about the prediction of soil pollution (ABAT et al., 2012).

In samples of tropical soils, Alleoni et al. (2005) reported that the Langmuir curve fitted well the adsorption of $\mathrm{Cu}$ and $\mathrm{Cd}$ in Oxisols and Ultisols with different degrees of weathering from Brazilian southeast. In the same region using Langmuir and Freundlich approaches, high coefficients of determination of equations to $\mathrm{Cd}$ and $\mathrm{Pb}$ in Oxisols and highly weathered Ultisols were observed (LINHARES et al., 2009). The correlation of chemical, physical and mineralogical attributes with adsorption parameters demonstrates that metal adsorption equations assists in the identification of factors that greatly influence the movement and bioavailability of toxic elements in the soil (HUANG et al., 2014).

Several authors have reported that the soil attributes that are more representative in heavy metals adsorption are the $\mathrm{pH}$, organic matter (OM), cation exchange capacity (CEC) and $\mathrm{Fe}$ and $\mathrm{Al}$ oxides (BRADL, 2004; VIOLANTE et al., 2010; CERQUEIRA et al., 2011a). Whereas that there is a significant influence of $\mathrm{CEC}$ and $\mathrm{OM}$ on $\mathrm{Cu}$ adsorption (ABAT et al., 2012) and of $\mathrm{pH}$ on $\mathrm{Cd}$ adsorption (GRAY et al., 1998). In addition to these attributes is $\mathrm{MnO}$, which even at low concentrations in the soil has high reactivity for adsorbing many heavy metals (KÄMPF et al., 2009; BRAZ et al., 2013a, 2013b). Although, several studies converge on the soil chemical properties as the most influential in the adsorption of metals in different regions around the world (ARIAS et al., 2005; CERQUEIRA et al., 2011b), there are few publications with Amazonian soils (BRAZ et al., 2013a).

Total concentrations of $\mathrm{Cu}$ above normal highlighting environmental risk have been observed in surrounding soil to a pilot project (Salobo project) of mineral extraction in Carajás - Amazon southeast (CASSELLA et al., 2006). Similarly, soils contaminated with $\mathrm{Cd}$ both the mineral activity (MAGALHÃES et al., 2011) and by agriculture (GONÇALVES JÚNIOR et al., 2014) have received extensive attention from environmental agencies in other regions. The existence of very different soil 
types in the Amazon region requires more studies evaluating its contrasting differences in chemical and physical attributes, such as high clay content $(>$ $\left.900 \mathrm{~g} \mathrm{~kg}^{-1}\right)$, rate weathering and influence of oxides (titanium, manganese and silicon) on pollutant retention.

The objective was to evaluate $\mathrm{Cu}$ and $\mathrm{Cd}$ adsorption and the correlation of the Langmuir and Freundlich equation parameters with contrasting chemical, physical and mineralogical attributes of Amazon soils.

\section{Materials and Methods}

Surface $(0-0.2 \mathrm{~m})$ and subsurface $(0.8-1.0 \mathrm{~m})$ samples were collected in six regions of the state of Pará in the areas of primary and secondary forest for more than 20 years (SINGH; STEINNES, 1994). To perform soil sampling, a Dutch auger manufactured in stainless steel and plastic basins was used to avoid possible sample contamination (CETESB, 2001). The collection areas were recorded with the GPS (eTrex 30, Garmin, USA). For each area of approximately 20 hectare with similar characteristics in color, soil texture, topography, drainage and vegetation cover, three composite samples were collected at both depths from 10 single samples, as suggested by Embrapa (2009). The following soil classes belong to the sampled areas: Xanthic

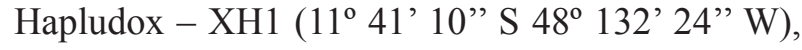
Xanthic Hapludox - XH2 (21 ${ }^{\circ} 59^{\prime} 45^{\prime \prime}$ S $47^{\circ} 121^{\prime}$ 10" W), Typic Hapludox - TH (60 00' 03" S 49 00' 55” W), Typic Rhodudalf -TR ( $31^{\circ} 17^{\prime} 41^{\prime \prime} \mathrm{S}$ $52^{\circ} 134^{\prime} 13$ ' W), Typic Fluvaquent -TF (1'27' 54" S $\left.48^{\circ} 26^{\prime} 10^{\prime \prime}\right)$ and Amazonian Dark Earths - ADE (01 45' 12" S 48 131'00" W).

The samples were air dried and sieved through a polyethylene mesh opening with a $2.0 \mathrm{~mm}$ diameter for the chemical, physical and mineralogical analyses. The $\mathrm{pH}$ was determined potentiometrically using a soil:water ratio of 1:2.5. The exchangeable content of calcium $(\mathrm{Ca})$ and magnesium $(\mathrm{Mg})$ extracted with a $1 \mathrm{M}$ solution of potassium chloride $(\mathrm{KCl})$. The content exchangeable $\mathrm{Ca}$ and $\mathrm{Mg}$ were quantified using atomic absorption spectrophotometry. Potassium (K) extracted using a Mehlich $1\left(0.05 \mathrm{M} \mathrm{HCl}+0.0125 \mathrm{M} \mathrm{H}_{2} \mathrm{SO}_{4}\right)$ solution; the $\mathrm{K}$ content was then determined using flame photometry (EMBRAPA, 2011). Using these results, the values of the CEC were calculated. The organic carbon content was determined using the WalkleyBlack method, which oxidizes the organic matter in a moist environment with potassium dichromate and then quantifies the organic matter by titration with $0.1 \mathrm{M}$ ammonium iron sulfate (NELSON; SOMMERS, 1982) and the result converted into OM using the factor 1.724 (EMBRAPA, 2011). The particle size was determined using the densitometer method as described by Gee and Or (2002).

The contents of oxides (expressed $\mathrm{Al}_{2} \mathrm{O}_{3}, \mathrm{Fe}_{2} \mathrm{O}_{3}$, $\mathrm{TiO}_{2}$, and $\mathrm{MnO}$ ) were extracted using a $9 \mathrm{M} \mathrm{H}_{2} \mathrm{SO}_{4}$ solution, whereas $\mathrm{Si}$, expressed as $\mathrm{SiO}_{2}$, was extracted using a $1 \mathrm{M} \mathrm{NaOH}$ solution (EMBRAPA, 2011). The Fe, Mn and Al contents were determined using atomic absorption spectrophotometry (AAS); those of Ti were determined using colorimetry, and those of $\mathrm{Si}$ were determined using gravimetry. The levels of $\mathrm{SiO}_{2}, \mathrm{Fe}_{2} \mathrm{O}_{3}, \mathrm{Al}_{2} \mathrm{O}_{3}, \mathrm{MnO}$ and $\mathrm{TiO}_{2}$, as well as the $\mathrm{Ki}$ and $\mathrm{Kr}$ weathering index, were measured according to the molar relation method that were described by the Brazilian Agricultural Research Corporation (EMBRAPA, 2011).

For interpretation of soil chemical properties were used the values originally proposed by Alvarez Venegas et al. (1999) and adapted by Moreira and Fageria (2009) for the state of Amazonas soils, to sort the attributes in five quantitative categories: very low, low, medium, high and very high.

For the curves of $\mathrm{Cd}$ and $\mathrm{Cu}$ adsorption, $2 \mathrm{~g}$ of ADFE (air-dried fine earth) in triplicate was added to $20 \mathrm{~mL}$ of $0.0025 \mathrm{M} \mathrm{CaCl}_{2}$ solution (supporting electrolyte) containing concentrations of $\mathrm{Cd}(0.0$; $3.99 ; 7.8 ; 19 ; 37.5 ; 67.3 ; 101.1$; and $120.0 \mathrm{mg} / \mathrm{L})$ and $\mathrm{Cu}$ concentrations $(0.0 ; 5.0 ; 10.0 ; 18.7 ; 38.4$; $86.6 ; 135.4$; and $171.8 \mathrm{mg} / \mathrm{L})$. The suspensions were 
stirred for $24 \mathrm{~h}$, centrifuged for $3 \mathrm{~min}$ at $3040 \mathrm{r} / \mathrm{min}$ and filtered through qualitative paper. In the extracts, the $\mathrm{Cd}$ and $\mathrm{Cu}$ concentrations were determined by atomic absorption spectrophotometry.

The concentrations of $\mathrm{Cd}$ and $\mathrm{Cu}$ as adsorbed to the soil were calculated according to the following expression: $\mathrm{C}_{\mathrm{ads}}=\left(\mathrm{C}_{0}-\mathrm{C}_{\mathrm{eq}}\right) \mathrm{DF}$, where $\mathrm{C}_{\text {ads }}$ is the amount of the metal that is retained in the solid phase, $\mathrm{C}_{0}$ is the concentration of heavy metals in solution after shaking, and DF is the dilution factor, which considers the solution:soil ratio according to equation (1):

$$
D F=\frac{20 \text { ml of Solution }}{2 \mathrm{gADFE}}
$$

The Langmuir and Freundlich equations were applied to fit the data from the isotherm studies, equations (2) and (3):

$$
\begin{gathered}
q e=\frac{K_{L} q_{m} C_{e}}{1}+K_{L} C_{\theta} \\
q e=K_{F} C_{e}^{\frac{1}{n}}
\end{gathered}
$$

where $q_{e}$ is the amount of adsorbed metal concentration at equilibrium $\left(\mathrm{mg} \mathrm{kg}^{-1}\right) ; \mathrm{C}_{\mathrm{e}}$ is the concentration of the metal in solution at equilibrium $\left(\mathrm{mg} \mathrm{L}^{-1}\right) ; \mathrm{q}_{\mathrm{m}}$ is the maximum adsorption amount of metal onto the soil $\left(\mathrm{mg} \mathrm{kg}^{-1}\right) ; \mathrm{K}_{\mathrm{L}}\left(\mathrm{L} \mathrm{kg}^{-1}\right)$ is the affinity constant for the Langmuir isotherm; $\mathrm{K}_{\mathrm{F}}\left(\mathrm{L} \mathrm{kg}^{-1}\right)$ is the adsorption coefficient; and $n$ is a dimensionless parameter that is related to the slope of the curve and that indicates the affinity of the solute in the ground by the Freundlich isotherm.

The maximum adsorption capacity and affinity for $\mathrm{Cu}$ and $\mathrm{Cd}$ among different soils were submitted to analysis of variance and when significant the F test compared by Tukey test at 5\% probability. In addition, we carried out a Pearson correlation analysis between the soil properties and the parameters of the adsorption curves.

\section{Results and Discussion}

The soils presented a very low or low $\mathrm{pH}$ (MOREIRA; FAGERIA, 2009) (Table 1). In surficial layer, cation exchange capacity (CEC) of TR and both depths of Typic Fluvaquent (TF) were classified as very high, whereas in other soils, values range from very low to high. The organic matter (OM) was very high in all samples regardless of the depth, according to Moreira and Fageria (2009). Soils presented large textural variation (Table 1). The surface layer ranged from 128 (XH1) - $729 \mathrm{~g} \mathrm{~kg}^{-1}$ (XH2) and was characterized as clayey to very clayey, respectively. The subsurface layer ranged from sandy clay loam $\left(189 \mathrm{~g} \mathrm{~kg}^{-1}\right)$ in ADE to very clayey $\left(931 \mathrm{~g} \mathrm{~kg}^{-1}\right)$ in $\mathrm{XH} 2$. The TF presented a silt-clay-loam texture with a predominance of silt. The Ki values indicate the degree of alteration of the soils, demonstrating weathering by the proportion between kaolinite and gibbsite, whereas $\mathrm{Kr}$ indicates the degree of alteration of minerals in soils by the ratio of $\mathrm{Fe}$ to $\mathrm{Al}$.

Amazonian soils those are naturally acidic, mainly due to the rapid mineralization of organic matter (SILVA JUNIOR et al., 2012). Very high CEC observed in TF are due to the large sediment deposition, typical in this type of soil (ABREU et al., 2007). Higher concentration of organic matter on the surface related to the addition of biomass of plant cover of sampling sites and the accelerated process of decomposition of this material. The TR, $\mathrm{TH}$ and XH2 samples showed the largest levels of oxides, especially TR, with very superior quantities of $\mathrm{TiO}_{2}$ and $\mathrm{MnO}$. This latter mineral, although found in small amounts in soils, has a significant influence on soil reactivity, and among the metals, the $\mathrm{Cu}^{2+}$ is the second most absorbed by manganese oxides (KÄMPF et al., 2009). 
Table 1. Chemistry, granulometry and mineralogy attributes of Amazonian soils.

\begin{tabular}{|c|c|c|c|c|c|c|c|c|c|c|c|c|c|c|}
\hline \multirow{2}{*}{ Soill $^{a}$} & \multirow{2}{*}{ Depth } & \multirow{2}{*}{$\mathrm{pH} \mathrm{H} \mathrm{H}_{2} \mathrm{O}$} & CEC & $\mathrm{OM}$ & Clay & Silt & Sand & $\mathrm{SiO}_{2}$ & $\mathrm{Al}_{2} \mathrm{O}_{3}$ & $\mathrm{Fe}_{2} \mathrm{O}_{3}$ & $\mathrm{TiO}_{2}$ & $\mathrm{MnO}$ & \multirow{2}{*}{$\mathrm{Ki}$} & \multirow{2}{*}{$\mathrm{Kr}$} \\
\hline & & & $\mathrm{mmol}_{\mathrm{c}} \mathrm{dm}^{-3}$ & \multicolumn{9}{|c|}{$\mathrm{g} \mathrm{kg}^{-1}$} & & \\
\hline \multirow{2}{*}{ XH1 } & Surf. & 3.8 & 16.3 & 22.6 & 128 & 120 & 752 & 32 & 42.3 & 91.0 & 42.6 & 0.08 & 1.29 & 1.13 \\
\hline & Sub. & 4.1 & 8.8 & 11.5 & 202 & 141 & 657 & 68 & 85.0 & 13.7 & 67.9 & 0.09 & 1.36 & 1.23 \\
\hline \multirow{2}{*}{$\mathrm{XH} 2$} & Surf. & 4.4 & 21.9 & 27.3 & 729 & 195 & 76 & 247 & 284.7 & 35.3 & 125.5 & 0.24 & 1.47 & 1.37 \\
\hline & Sub. & 4.5 & 9.1 & 11.2 & 931 & 41 & 28 & 268 & 313.3 & 40.8 & 123.6 & 0.15 & 1.45 & 1.34 \\
\hline \multirow{2}{*}{$\mathrm{ADE}$} & Surf. & 4.8 & 55.9 & 28.5 & 139 & 79 & 782 & 45 & 47.7 & 25.8 & 29.9 & 0.27 & 1.60 & 1.19 \\
\hline & Sub. & 4.9 & 27.9 & 11.8 & 189 & 70 & 741 & 59 & 66.4 & 32.6 & 46.4 & 0.23 & 1.51 & 1.15 \\
\hline \multirow{2}{*}{$\mathrm{TH}$} & Surf. & 4.4 & 25.2 & 28.5 & 642 & 62 & 296 & 146 & 185.9 & 172.7 & 127.4 & 0.29 & 1.34 & 0.84 \\
\hline & Sub. & 4.4 & 3.0 & 12.7 & 747 & 18 & 235 & 166 & 207.1 & 202.0 & 132.5 & 0.27 & 1.36 & 0.84 \\
\hline \multirow{2}{*}{ TR } & Surf. & 5.1 & 72.4 & 19.8 & 539 & 177 & 284 & 156 & 143.4 & 139.0 & 388.2 & 3.46 & 1.85 & 1.14 \\
\hline & Sub. & 4.9 & 45.8 & 9.3 & 737 & 96 & 167 & 198 & 191.2 & 152.3 & 280.6 & 2.19 & 1.76 & 1.17 \\
\hline \multirow{2}{*}{$\mathrm{TF}$} & Surf. & 3.9 & 88.2 & 25.1 & 301 & 679 & 20 & 119 & 71.7 & 30.1 & 42.6 & 0.44 & 2.82 & 2.22 \\
\hline & Sub. & 4.3 & 97.6 & 9.9 & 299 & 654 & 47 & 177 & 95.6 & 50.3 & 57.1 & 1.26 & 3.15 & 2.35 \\
\hline
\end{tabular}

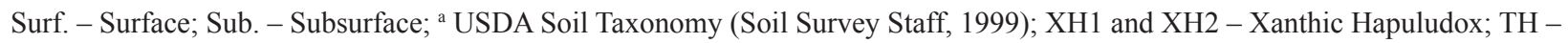
Typic Hapludox, TR - Typic Rhodudalf, TF - Typic Fluvaquent and Amazonian Dark Earths - ADE.

All of the soils were kaolinitic ( $\mathrm{Ki}$ and $\mathrm{Kr}>0.75)$ (IBGE, 2007). In the samples of XH1, XH2 and TH, the values of $\mathrm{Ki}$ were lower and accompanied by high $\mathrm{Kr}$ values, indicating the oxidic and weathering state of the samples, which was confirmed by the poor fertility of soils (BRAZ et al., 2013a), which may result in a lower adsorption of pollutant metals. In contrast, the greatest value of $\mathrm{Ki}$ and the fertility to TF were observed, demonstrating less-intense weathering, which is justified because this soil is formed from the deposition of sediments due to flooding (ABREU et al., 2007).

Values of metal adsorption fitted well with the Langmuir and Freundlich models (Figures 1 and 2), as evidenced by satisfactory correlation coefficients (Table 2). The metal adsorption increased with the increasing rates of addition (PETRUZZELLI et al., 1985; ROSS, 1994), where the $\mathrm{Cu}^{2+}$ was more adsorbed than $\mathrm{Cd}^{2+}$ considering the individual adsorption system. The surface layer adsorption was larger than that of the subsurface, as evidenced by higher levels of OM, CEC and $\mathrm{pH}$ attributes.

For $\mathrm{Cu}^{2+}$ in all soils and $\mathrm{Cd}^{2+}$ in the surficial samples of TR, the isotherms were of $\mathrm{H}$ type (High), according the classification proposed by Giles et al. (1974), which refers to a convex shape. The isotherm $\mathrm{H}$ type assigned to a highaffinity metal-adsorbent surface. Another factor is that the high $\mathrm{Cu}$ adsorption in the low equilibrium solution concentrations followed by an adsorption attenuation in major concentrations indicates the probability that the adsorption process of this metal has two steps that can linked to the occupation of different sites (MOREIRA; ALLEONI, 2010). For $\mathrm{Cd}^{2+}$, in most of the soils, the isotherms were of $\mathrm{L}$ type (Langmuir), which characterizes the minor energy of adsorption as expressed by the low slope of the curves due to the decreased adsorption sites when the adsorbent surface coverage increases. 
Figure 1. Adsorption isotherms of $\mathrm{Cu}$ and $\mathrm{Cd}$ in Xanthic Hapludox 1 (A, B); Xanthic Hapludox 2 (C, D) and Amazonian Dark Earths (E, F).

Surface

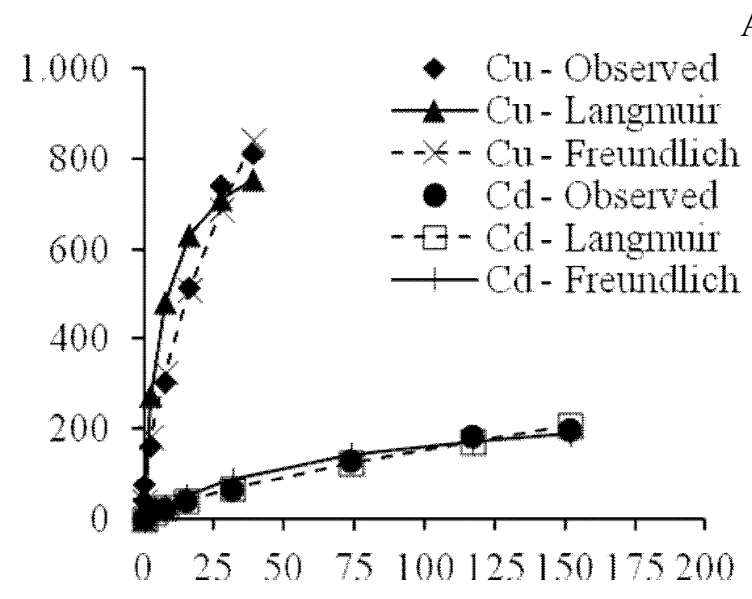

A

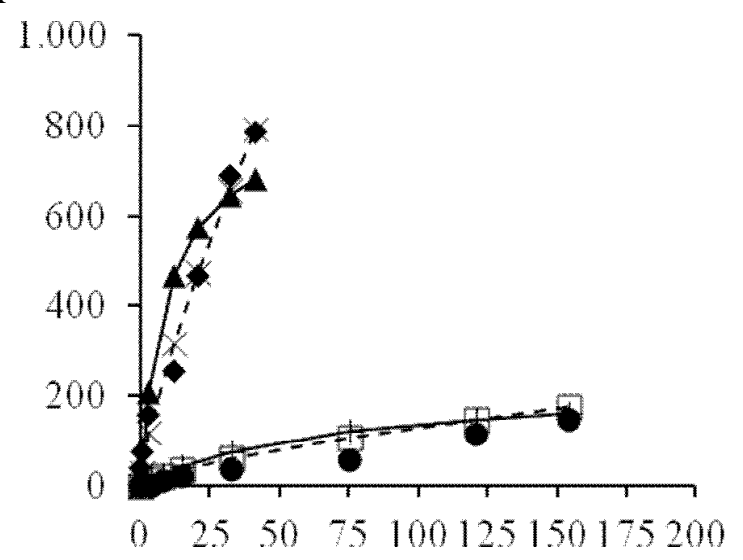

B
A

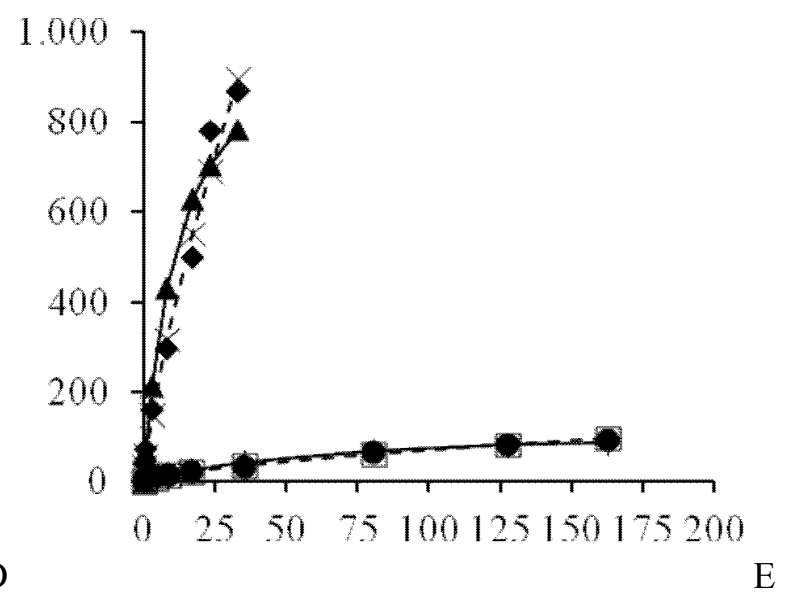


Figure 2. Adsorption isotherms of $\mathrm{Cu}$ and $\mathrm{Cd}$ in Typic Hapludox (A, B); Typic Rhodudalf(C, D) and Typic Fluvaquent (E, F).

Surface

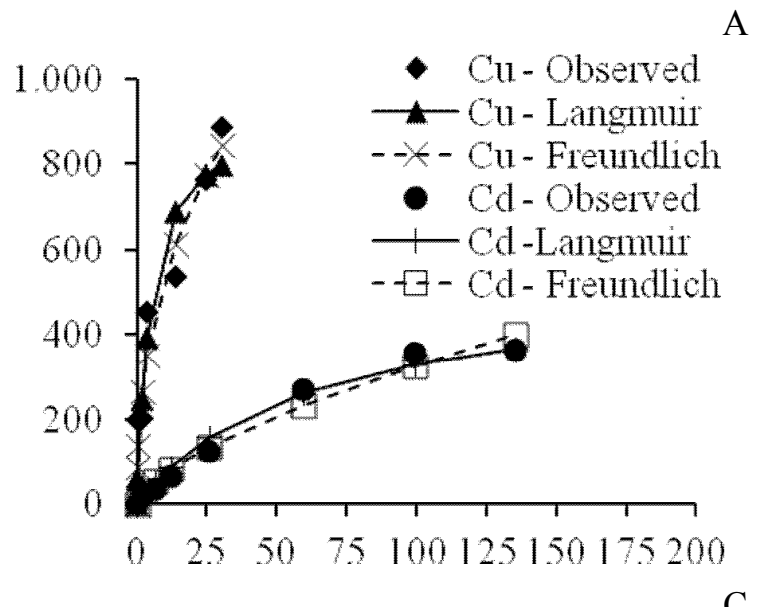

A
Subsurface
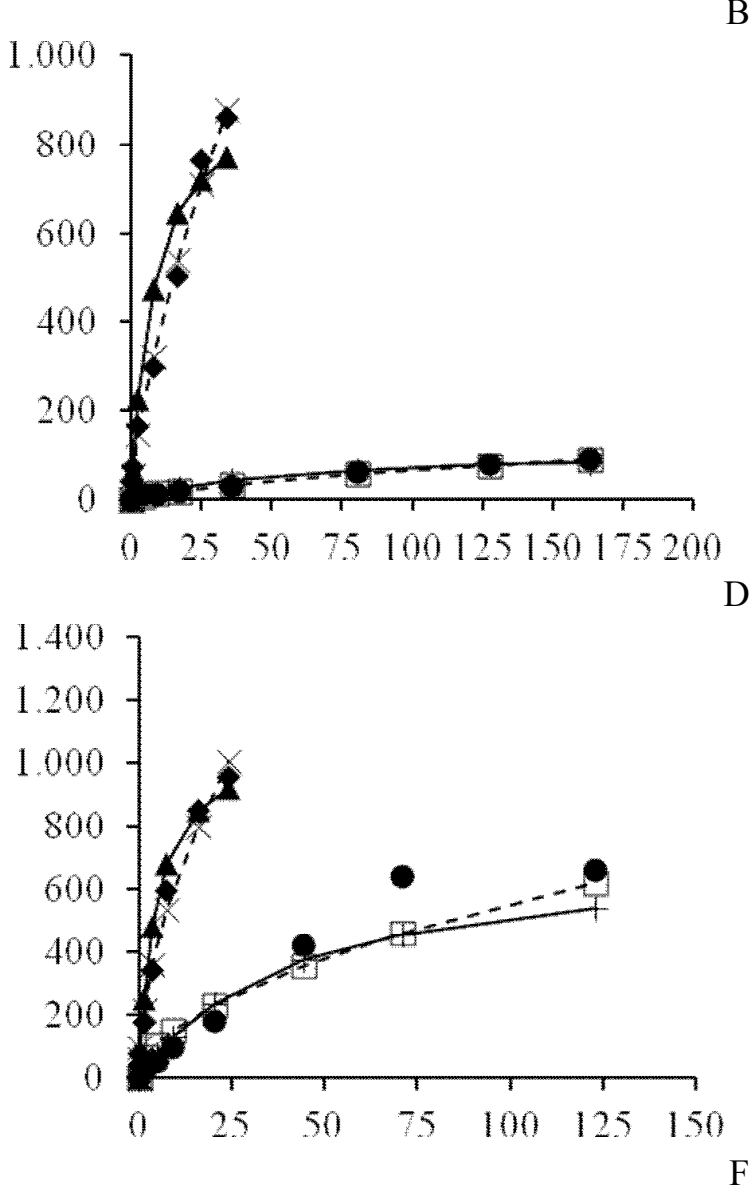

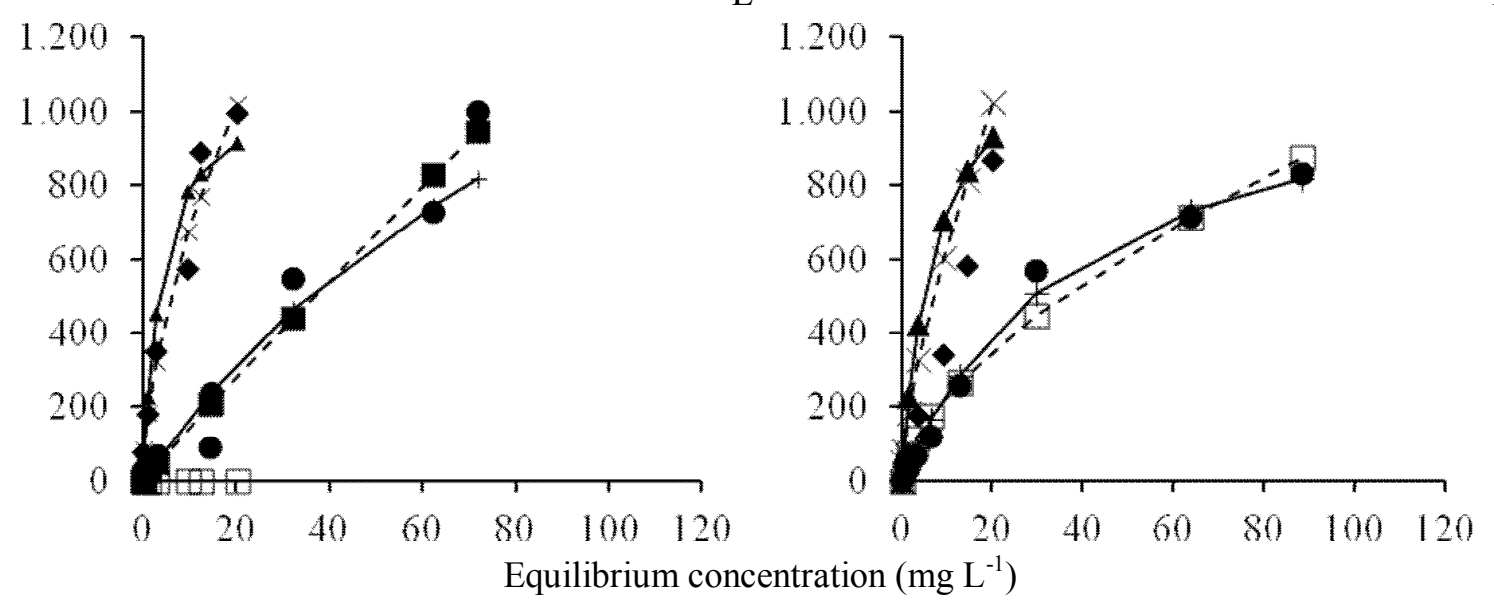


The low adsorption of $\mathrm{Cd}^{2+}$ in the Amazon soils, excepting TR surface, indicates that a great migration of this metal through the soil profile may occur when $\mathrm{Cd}^{2+}$ is added to the environment. The $\mathrm{Cd}^{2+}$ migration was observed by Dère et al. (2006) in irrigated sand Luvisol in North-West Paris. Soils with the greater adsorption of $\mathrm{Cu}^{2+}$ and $\mathrm{Cd}^{2+}$ in the Langmuir and Freundlich models were TF, ADE and TR, highlighting the TF in Langmuir equation at both depths and the TR in the Freundlich equation in surficial layer. TR and ADE showed elevated $\mathrm{pH}$ and CEC compared to those of the other soils (Table 1), which can contribute to the greater adsorption of metallic cations. The increase in the dependent charges in the soil promotes the competitive decrease of $\mathrm{H}^{+}$in complexation sites of organic matter favoring metal adsorption (ALLOWAY, 1995).

Table 2. Adsorption parameters of $\mathrm{Cu}$ and $\mathrm{Cd}$ curves in the soils of eastern Amazonia.

\begin{tabular}{|c|c|c|c|c|c|c|c|c|c|}
\hline \multirow{3}{*}{ Soila $^{\mathrm{a}}$} & \multirow{3}{*}{ Depth } & \multicolumn{8}{|c|}{ Langmuir } \\
\hline & & \multicolumn{4}{|c|}{$\mathrm{Cu}$} & \multicolumn{4}{|c|}{$\mathrm{Cd}$} \\
\hline & & $\mathrm{qm}$ & $\mathrm{K}_{\mathrm{L}}$ & $\mathrm{R}^{2}$ & & $\mathrm{qm}$ & $\mathrm{K}_{\mathrm{L}}$ & $\mathrm{R}^{2}$ & \\
\hline \multirow{2}{*}{ XH1 } & Surface & $825.1 \mathrm{f}$ & $0.17^{\mathrm{L}} \mathrm{def}$ & 0.89 & $*$ & $268.7 \mathrm{e}$ & $0.015^{\mathrm{L}} \mathrm{de}$ & 0.99 & $* *$ \\
\hline & Subsurface & 864.2 ef & 0.11 ef & 0.92 & $* *$ & $274.7 \mathrm{e}$ & $0.013 \mathrm{e}$ & 0.96 & $* *$ \\
\hline \multirow{2}{*}{ XH2 } & Surface & $964.1 \mathrm{~d}$ & $0.15 \mathrm{def}$ & 0.89 & $*$ & $231.4 \mathrm{e}$ & $0.027 \mathrm{~cd}$ & 0.93 & $* *$ \\
\hline & Subsurface & $1064.8 \mathrm{c}$ & $0.08 \mathrm{f}$ & 0.95 & $* *$ & $120.2 \mathrm{e}$ & $0.015 \mathrm{de}$ & 0.96 & $* *$ \\
\hline \multirow{2}{*}{$\mathrm{ADE}$} & Surface & $1165.5 \mathrm{~b}$ & $0.33 \mathrm{ab}$ & 0.91 & $*$ & $1180.3 \mathrm{~b}$ & $0.069 \mathrm{~b}$ & 0.92 & $* *$ \\
\hline & Subsurface & 933.4 de & $0.38 \mathrm{~b}$ & 0.90 & $*$ & 822.9 c & $0.034 \mathrm{c}$ & 0.96 & $* *$ \\
\hline \multirow{2}{*}{$\mathrm{TH}$} & Surface & $919.1 \mathrm{de}$ & 0.23 cdef & 0.91 & $*$ & $544.8 \mathrm{~d}$ & $0.015 \mathrm{de}$ & 0.98 & $* *$ \\
\hline & Subsurface & 947.1 d & 0.13 def & 0.96 & $* *$ & $115.6 \mathrm{e}$ & $0.015 \mathrm{de}$ & 0.98 & $* *$ \\
\hline \multirow{2}{*}{$\mathrm{TR}$} & Surface & $1072.5 \mathrm{c}$ & $1.82 \mathrm{a}$ & 0.82 & $*$ & $1283.6 \mathrm{~b}$ & $0.246 \mathrm{a}$ & 0.95 & $* *$ \\
\hline & Subsurface & $1076.4 \mathrm{c}$ & 0.23 bcde & 0.90 & $*$ & $724.6 \mathrm{c}$ & $0.025 \mathrm{cde}$ & 0.93 & $* *$ \\
\hline \multirow{4}{*}{$\mathrm{TF}$} & Surface & $1106.5 \mathrm{bc}$ & $0.26 \mathrm{bcd}$ & 0.92 & $* *$ & $1505.9 \mathrm{a}$ & $0.018 \mathrm{de}$ & 0.99 & $* *$ \\
\hline & Subsurface & $1260.1 \mathrm{a}$ & 0.14 def & 0.95 & $* *$ & $1190.1 \mathrm{~b}$ & 0.024 cde & 0.96 & $* *$ \\
\hline & & \multicolumn{8}{|c|}{ Freundlich } \\
\hline & & \multicolumn{4}{|c|}{$\mathrm{Cu}$} & \multicolumn{4}{|c|}{$\mathrm{Cd}$} \\
\hline \multirow{3}{*}{ XH1 } & & $\mathrm{K}_{\mathrm{F}}$ & $\mathrm{n}$ & $\mathrm{R}^{2}$ & & $\mathrm{~K}_{\mathrm{F}}$ & $\mathrm{n}$ & $\mathrm{R}^{2}$ & \\
\hline & Surface & 107.2 def & $0.58 \mathrm{bc}$ & 0.97 & $* *$ & $6.12 \mathrm{fg}$ & $0.701 \mathrm{abc}$ & 0.96 & $* *$ \\
\hline & Subsurface & $55.2 \mathrm{f}$ & $0.75 \mathrm{a}$ & 0.99 & $* *$ & $5.21 \mathrm{~g}$ & $0.697 \mathrm{bc}$ & 0.99 & $* *$ \\
\hline \multirow{2}{*}{ XH2 } & Surface & 138.1 cde & $0.54 \mathrm{~cd}$ & 0.96 & $* *$ & $11.34 \mathrm{fg}$ & $0.681 \mathrm{bcd}$ & 0.97 & $* *$ \\
\hline & Subsurface & 69.7 ef & $0.73 \mathrm{a}$ & 0.99 & $* *$ & $2.89 \mathrm{~b}$ & $0.579 \mathrm{de}$ & 0.99 & $* *$ \\
\hline \multirow{2}{*}{$\mathrm{ADE}$} & Surface & $291.9 \mathrm{~b}$ & $0.45 \mathrm{~d}$ & 0.95 & $* *$ & $93.49 \mathrm{~b}$ & $0.576 \mathrm{de}$ & 0.98 & $* *$ \\
\hline & Subsurface & $200.3 \mathrm{c}$ & $0.46 \mathrm{~d}$ & 0.97 & $* *$ & $26.77 \mathrm{e}$ & $0.724 \mathrm{a}$ & 0.99 & $* *$ \\
\hline \multirow{2}{*}{$\mathrm{TH}$} & Surface & $142.2 \mathrm{cde}$ & $0.53 \mathrm{~cd}$ & 0.95 & $* *$ & $15.84 \mathrm{f}$ & 0.658 bcde & 0.99 & $* *$ \\
\hline & Subsurface & 80.2 ef & $0.68 \mathrm{ab}$ & 0.99 & $* *$ & $2.71 \mathrm{~b}$ & $0.703 \mathrm{abc}$ & 0.99 & $* *$ \\
\hline \multirow{2}{*}{$\mathrm{TR}$} & Surface & $458.6 \mathrm{a}$ & $0.30 \mathrm{e}$ & 0.92 & $* *$ & $243.11 \mathrm{a}$ & $0.431 \mathrm{f}$ & 0.85 & $* *$ \\
\hline & Subsurface & $177.9 \mathrm{~cd}$ & $0.53 \mathrm{~cd}$ & 0.97 & $* *$ & $44.88 \mathrm{~d}$ & $0.547 \mathrm{e}$ & 0.97 & $* *$ \\
\hline \multirow{2}{*}{$\mathrm{TF}$} & Surface & $199.6 \mathrm{c}$ & $0.54 \mathrm{~cd}$ & 0.97 & $* *$ & $29.29 \mathrm{e}$ & 0.809 a & 0.99 & $* *$ \\
\hline & Subsurface & $138.1 \mathrm{cde}$ & $0.63 \mathrm{abc}$ & 0.98 & $* *$ & $56.40 \mathrm{c}$ & $0.610 \mathrm{cde}$ & 0.98 & $* *$ \\
\hline
\end{tabular}

qm (mg kg-1); aUSDA Soil Taxonomy (Soil Survey Staff, 1999); XH1 and XH2 - Xanthic Hapludox; TH - Typic Hapludox, TR Typic Rhodudalf, TF - Typic Fluvaquent and Amazonian Dark Earths - ADE. 
Similar to maximum adsorption, the constants $\mathrm{K}_{\mathrm{L}}$ of Langmuir and $n$ of Freundlich showed a greater affinity in TR, ADE and TF to the studied metals to the detriment of XH1, XH2 and TF. The $n$ parameter, in turn, is interpreted in the reverse way of $\mathrm{K}_{\mathrm{L}}$, in that a greater $n$ means a smaller affinity of adsorbent to the adsorbate. This low retention of metal of Amazon Oxisols concerns the agricultural sector because these soils constitute $41 \%$ of total areas of this region. Langmuir maximum adsorption and the Freundlich $\mathrm{Kf}$ parameter of $\mathrm{Cu}$ ranged from 825 to $1260 \mathrm{mg} \mathrm{kg}^{-1}$ and from 55.3 to $458.6 \mathrm{mg} \mathrm{kg}^{-}$ ${ }^{1}$, respectively. These same variables of $\mathrm{Cd}$ ranged from 115.6 to 1506 and 2.7 to 243.1 , respectively (Table 2). The results are similar to the values that were reported by Alleoni et al. (2005) in five Oxisols, two Alfisols and one Ultisol in relation to the $\mathrm{Cu}^{2+}$ in Southeast Brazil and, in this same region and similar to that observed by Linhares et al. (2009), to the $\mathrm{Cd}^{2+}$ in four Oxisols and one highly weathered Ultisol.
Linear correlation coefficients between the soil properties and the parameters of the adsorption isotherms (Table 3) indicate that the $\mathrm{pH}$, OM, $\mathrm{CEC}, \mathrm{MnO}, \mathrm{Ki}$ and $\mathrm{Kr}$ are mainly responsible for the maximum adsorption of and $\mathrm{Cd}^{2+}$. The $\mathrm{Cu}^{2+}$ adsorption was 58 times higher in limed soils than in non-limed soils in Malaysia (ABAT et al., 2012). This fact was related to the CEC elevation in soils that received lime, mainly to CEC-dependent $\mathrm{pH}$ (organic matter), which increases the negative charge to metal adsorption. The $\mathrm{Cd}^{2+}$ adsorption is significantly influenced by $\mathrm{pH}$, fact that overcomes even mineralogical properties: while at higher $\mathrm{pH}$ values, it increases the amount of high-affinity sites that are occupied by the metal in the adsorptionspecific mechanism (GRAY et al., 1998). The bond of $\mathrm{Cd}^{2+}$ and metal oxides also depends on the $\mathrm{pH}$ determining the adsorption to be specific, nonspecific and electrostatic mechanisms (ALLEONI et al., 2005).

Table 3. Correlation coefficient between the soil attributes and parameters of adsorption isotherms Langmuir and Freundlich for copper $(\mathrm{Cu})$ and cadmium $(\mathrm{Cd})$.

\begin{tabular}{|c|c|c|c|c|c|c|c|c|c|c|c|}
\hline \multirow{3}{*}{ Soil attributes } & \multicolumn{5}{|c|}{ Langmuir } & \multicolumn{6}{|c|}{ Freundlich } \\
\hline & \multicolumn{3}{|c|}{$\mathrm{Cu}$} & \multicolumn{2}{|c|}{$\mathrm{Cd}$} & \multicolumn{3}{|c|}{$\mathrm{Cu}$} & \multicolumn{3}{|c|}{$\mathrm{Cd}$} \\
\hline & $\mathrm{qm}$ & & $\mathrm{K}_{\mathrm{L}}$ & $\mathrm{qm}$ & $\mathrm{K}_{\mathrm{L}}$ & $\mathrm{K}_{\mathrm{F}}$ & & $\mathrm{n}$ & $\mathrm{K}_{\mathrm{F}}$ & & $\mathrm{n}$ \\
\hline $\mathrm{pH}_{\mathrm{H} 2 \mathrm{O}}$ & 0.41 & & 0.38 & 0.54 & -0.61 & 0,65 & $*$ & 0.38 & 0,69 & $*$ & $-0.68 *$ \\
\hline $\mathrm{CEC}$ & 0.91 & $* *$ & 0.19 & 0.32 & -0.34 & 0.17 & & 0.22 & 0.18 & & -0.18 \\
\hline $\mathrm{OM}$ & 0.83 & $*$ & 0.31 & 0.58 & -0.54 & 0.94 & $* *$ & 0.33 & 0.50 & & -0.34 \\
\hline Clay & 0.07 & & -0.02 & -0.12 & 0.12 & -0.42 & & -0.02 & -0.09 & & -0.10 \\
\hline Silt & 0.51 & & -0.05 & 0.06 & 0.02 & 0.44 & & -0.04 & 0.09 & & 0.07 \\
\hline Sand & -0.52 & & 0.06 & 0.07 & -0.12 & -0.08 & & 0.05 & 0.02 & & 0.04 \\
\hline $\mathrm{SiO}_{2}$ & 0.35 & & -0.06 & -0.11 & 0.13 & -0.24 & & -0.02 & -0.04 & & -0.19 \\
\hline $\mathrm{Al}_{2} \mathrm{O}_{3}$ & 0.02 & & -0.12 & -0.23 & 0.23 & -0.54 & & -0.09 & -0.18 & & -0.09 \\
\hline $\mathrm{Fe}_{2}^{2} \mathrm{O}_{3}^{3}$ & -0.01 & & 0.27 & 0.19 & -0.19 & -0.07 & & 0.21 & 0.20 & & -0.13 \\
\hline $\mathrm{TiO}_{2}^{2}$ & 0.09 & & 0.12 & 0.23 & -0.55 & 0.13 & & 0.39 & 0.45 & & -0.33 \\
\hline $\mathrm{MnO}$ & 0.39 & & $0.80 *$ & $0.77 *$ & $-0.70 *$ & 0.51 & & $0.78 *$ & 0.83 & $*$ & $-0.72 *$ \\
\hline $\mathrm{Ki}$ & 0.79 & $*$ & 0.05 & 0.20 & -0.12 & 0.74 & $*$ & 0.07 & 0.23 & & -0.06 \\
\hline $\mathrm{Kr}$ & 0.68 & $*$ & -0.15 & -0.02 & 0.09 & 0.56 & & -0.12 & 0.02 & & 0.06 \\
\hline
\end{tabular}

$\mathrm{CEC}$ - Cation exchange capacity; OM - Organic matter; qm $\left(\mathrm{mg} \mathrm{kg}^{-1}\right)$; ** and *, significant at 1 and $5 \%$, respectively. 
Entisols and Alfisols are $6.0 \%$ and $0.4 \%$ of Amazon soils, respectively. Entisols have high natural fertility, due mainly to sediments that are deposited on riverbanks during successive cycles of flooding (ABREU et al., 2007). A significant proportion of the rural population of the Amazonia (riverine) occupy these areas, which despite its high potential for adsorption of metals, these soils are at high risk for environmental pollution because the Amazonian cities still dump the majority of their waste in rivers. The Alfisols, in turn, have a small representation, although their high fertility supports important grazing areas in eastern Amazonia.

The correlation coefficient of the present study (Table 3) corroborate those that were obtained by Arias et al. (2005), who observed a positive correlation between the $\mathrm{pH}$ and the maximum adsorption and affinity coefficients of $\mathrm{Cu}^{2+}$ in 27 acid soils from Spain. According to Bradl (2004), the $\mathrm{pH}$ is the most important soil attribute that influences metal adsorption. These authors observed that a sediment compound of iron and aluminum oxide adsorbed $50 \%$ of the $\mathrm{Cu}^{2+}$ at $\mathrm{pH} 4.1$ and the increasing of $\mathrm{pH}$ tends to promote the maximum adsorption of $\mathrm{Cu}^{2+}$ faster than $\mathrm{Zn}^{2+}$ and $\mathrm{Cd}^{2+}$. In relation to organic matter, its positive correlation with adsorption parameters of $\mathrm{Cu}$ is a function of the strong binding between the elements with humic substances (STEVENSON, 1994). While the correlation between soil constant of affinity to $\mathrm{Cu}^{2+}$ and $\mathrm{MnO}$ is due to the role of this oxide as primary sink of heavy metals in its inner layers region that have high reactivity (VIOLANTE et al., 2010).

Soil attributes with significant coefficients to maximum adsorption and affinity of $\mathrm{Cd}$ was $\mathrm{MnO}$ in the Langmuir isotherm and $\mathrm{pH}$ and $\mathrm{MnO}$ in the Freundlich isotherm (Table 3). In highly weathered tropical Oxisols and Ultisols from southeastern Brazil, there was the highest correlation of $\mathrm{pH}$ with the maximum adsorption and binding energy of $\mathrm{Cd}$ (LINHARES et al., 2009, 2010), as well as a Humic Umbrisol, an Umbric Cambisol, an Endoleptic
Luvisol and an Humic Cambisol from Spain (CERQUEIRA et al., 2011a). According to Bradl (2004), the soil ability to adsorb Cd can increase three-fold with an increase of one unit in $\mathrm{pH}$; this parameter significantly influences the mobility of $\mathrm{Cd}$ in the soil, and at low values of this attribute, high metal leaching can occur (ALLOWAY, 1995; ADRIANO, 2001).

\section{Conclusions}

The Langmuir and Freundlich isotherms adequately described the $\mathrm{Cu}$ and $\mathrm{Cd}$ adsorption in soils. The surface layer of soil adsorbed more than the subsurface due to the higher content of organic matter. The $\mathrm{Cu}$ showed a greater maximum adsorption and affinity to the soils than $\mathrm{Cd}$ due to the high influence of $\mathrm{pH}$ and $\mathrm{CEC}$ on its retention. The Typic Rhodudalf, Typic Fluvaquent and Amazonian Dark Earths, due to their higher values of $\mathrm{pH}$, $\mathrm{CEC}, \mathrm{OM}$ and prominently $\mathrm{MnO}$, adsorbed more heavy metals than the Xanthic Hapludox and Typic Hapludox according to the parameters $\mathrm{qm}$ and $\mathrm{K}_{\mathrm{L}}$ of Langmuir and $\mathrm{K}_{\mathrm{F}}$ of Freundlich.

\section{Acknowledgments}

We thank the Brazilian National Council for Scientific and Technological Development (CNPq) for funding this research and Coordination for the Improvement of Higher Education Personnel (CAPES) through scholarships.

\section{References}

ABAT, M.; MCLAUGHLIN, M. J.; KIRBY, J. K.; STACEY, S. P. Adsorption and desorption of copper and zinc in tropical peat soils of Sarawak, Malaysia. Geoderma, Amsterdam, v. 175-176, p. 58-63, abr. 2012.

ABREU, E. M. A.; FERNANDES, A. R.; RUIVO, M. L. P. Variação temporal e vertical de atributos químicos de um Gleissolo do rio Guamá cultivado com canaranas. Revista Brasileira de Ciência do Solo, Viçosa, MG, v. 31, n. 2, p. 277-285, 2007. 
ADRIANO, D. C. Trace elements in terrestrial environments: biogeochemistry, bioavailability, and risks of metals. New York: Springer, 2001. 513 p.

ALLEONI, L. R. F.; IGLESIAS, C. S. M.; MELLO, S. de C.; CAMARGO, O. A. de; CASAGRANDE, J. C.; LAVORENTI, N. A. Atributos do solo relacionados à adsorção de cádmio e cobre em solos tropicais. Acta Scientiarum. Agronomy, Maringá, v. 27, n. 4, p. 729-737, 2005.

ALLOWAY, B. J. Heavy metals in soils. New York, London: Blackie Academic and Professional, 1995. 368 p.

ALVAREZ VENEGAS, V. H.; NOVAIS, R. F.; BARROS, N. F.; CATARUTTI, R. B.; LOPES, A. S. Interpretação dos resultados das análises de solos. In: RIBEIRO, A. C.; GUIMARÃES, P. T. G.; ALVAREZ VENEGAS, V. H. (Ed.). Recomendações para o uso de corretivos e fertilizantes em Minas Gerais. $5^{\text {a }}$ aproximação. Viçosa, MG: Comissão de Fertilidade do Solo do Estado de Minas Gerais, CFSEMG, 1999. p. 25-32.

ARIAS, M.; PÉREZ-NOVO, C.; OSORIO, F.; LÓPEZ, E.; SOTO, B. Adsorption and desorption of copper and zinc in the surface layer of acid soils. Journal of Colloid and Interface Science, New York, v. 288, n. 1, p. 21-9, 2005.

BRADL, H. B. Adsorption of heavy metal ions on soils and soils constituents. Journal of Colloid and Interface Science, New York, v. 277, n. 1, p. 1-18, 2004.

BRAZ, A. M. de S.; FERNANDES, A. R.; FERREIRA, J. R.; ALLEONI, L. R. F. Distribution coefficients of potentially toxic elements in soils from the eastern Amazon. Environmental Science and Pollution Research, Landsberg, v. 20, n. 10, p. 7231-7242, 2013a.

Prediction of the distribution coefficients of metals in Amazonian soils. Ecotoxicology and Environmental Safety, New York, v. 95, p. 212-220, set. 2013b.

CASSELLA, R. J.; WAGENERB, A. L. R.; SANTELLIA, R. E.; WAGENERC, K.; TAVARESC, L. Y. Distribution of copper in the vicinity of a deactivated mining sites at Carajas in the Amazon region of Brazil. Journal of Hazardous Materials, Amsterdam, v. 142, p. 543-549, 2007.

CERQueIRA, B.; COVELO, E. F.; ANDRADE, M. L.; VEGA, F. A. Retention and mobility of copper and lead in soils as influenced by soil horizon properties. Pedosphere, Nanjing, v. 21, n. 5, p. 603-614, 2011 a.

. The influence of soil properties on the individual and competitive sorption and desorption of $\mathrm{Cu}$ and $\mathrm{Cd}$. Geoderma, Amsterdam, v. 162, p. 20-26, 2011 b.
COMPANHIA DE TECNOLOGIA DE SANEAMENTO AMBIENTAL - CETESB. Relatório de estabelecimento de valores orientadores para solos e água subterrâneas no Estado de São Paulo. São Paulo: CETESB, 2001. 247 p.

DÈRE, C.; LAMY, I.; VAN OORT, F.; BAIZE, D.; CORNU, S. Trace metal inputs reconstitution and migration assessment in a sandy Luvisol after 100 years of massive irrigation with raw wastewater. Comptes Rendus Geoscience, Paris, v. 338, n. 8, p. 565-573, 2006.

EMPRESA BRASILEIRA DE PESQUISA AGROPECUÁRIA - EMBRAPA. Manual de análises químicas de solos, plantas e fertilizantes. Brasília: Embrapa Informação Tecnológica, 2009. 627 p.

. Manual de métodos de análises do solo. 2. ed. Rio de Janeiro: Embrapa Solos, 2011. 230 p.

GEE, G. W.; OR, D. Particle-size analysis. In: DANE, J. H.; TOOP, G. C. Methods of soil analysis, part 4: physical methods. 3. ed. Madson: Soil Science Society of America, 2002. p. 255-293.

GILES, C. H.; SMITH, D.; HUITSON, A. A. general treatment and classification of the solute adsorption isotherm. I. Theoretical. Journal of Colloid and Interface Science, New York, v. 47, n. 3, p. 755-765, 1974.

GONÇALVES JÚNIOR, A. C.; NACKE, H.; SCHWANTES, D.; COELHO, G. F. Heavy metal contamination in brazilian agricultural soils due to application of fertilizers. In: HERNANDEZ-SORIANO, M. C. (Ed.). Environmental risk assessment of soil contamination. Rijeka: Intech Open, 2014. p. 105-135.

GRAY, C. W.; MCLAREN, R. G.; ROBERTS, A. H. C.; CONDRON, L. M. Sorption and desorption of cadmium from some New Zealand soils: effect of $\mathrm{pH}$ and contact time. Australian Journal of Soil Research, Sydney, v. 36, n. 2, p. 199-216, 1998.

HUANG, B.; LI, Z.; HUANG, J.; GUO, L.; NIE, X.; WANG, Y.; ZHANG, Y.; ZENG, G. Adsorption characteristics of $\mathrm{Cu}$ and $\mathrm{Zn}$ onto various size fractions of aggregates from red paddy soil. Journal of Hazardous Materials, Amsterdam, v. 264, p. 176-183, 2014.

INSTITUTO BRASILEIRO DE GEOGRAFIA E ESTATÍSTICA - IBGE. Manual técnico de pedologia. 2. ed. Rio de Janeiro: IBGE, 2007. 316 p.

KÄMPF, N.; CURI, N.; MARQUES, J. J. Óxidos de alumínio, silício, manganês e titânio. In: MELO, V. F.; ALLEONI, L. R. F. (Ed.). Química e mineralogia do solo. Viçosa, MG: Sociedade Brasileira de Ciência do Solo, 2009. v. 1, p. 573-610.

LINHARES, L. A.; EGREJA FILHO, F. B.; BELLIS, V. M.; SANTOS, E. A. dos; IANHEZ, R. Utilização dos 
modelos de Langmuir e de Freundlich na adsorção de cobre e zinco em solos Brasileiros. Acta Agronômica, Palmira, v. 59, n. 3, p. 303-315, 2010.

LINHARES, L. A.; EGREJA FILHO, F. B.; OLIVEIRA, C. V. de; BELLIS, V. M. Adsorção de cádmio e chumbo em solos tropicais altamente intemperizados. Pesquisa Agropecuária Brasileira, Brasília, v. 44, n. 3, p. 291-299, mar. 2009.

MAGALHÃES, M. O. L.; AMARAL SOBRINHO, N. M. B. do; MAZUR, N. Uso de resíduos industriais na remediação de solo contaminado com cádmio e zinco. Ciência Florestal, Santa Maria, v. 21, n. 2, p. 219-227, abr./jun. 2011.

MOREIRA, A.; FAGERIA, N. K. Soil chemical attributes of Amazonas state, Brazil. Communications in Soil Science and Plant Analysis, New York, v. 40, n. 1718, p. 2912-2925, 2009.

MOREIRA, C. S.; ALLEONI, L. R. F. Adsorption of Cd, $\mathrm{Cu}, \mathrm{Ni}$ and $\mathrm{Zn}$ in tropical soils under competitive and non-competitive systems. Scientia Agricola, Piracicaba, v. 67, n. 3, p. 301-307, maio/jun. 2010.

NELSON, D. W.; SOMMERS, L. E. Total carbon, organic carbon and organic matter. In: PAGE, A. L.; MILLER, R. H.; KEENEY, D. R. (Ed.). Methods of soil analysis: chemical and microbiological properties. Part 2. Madison: Soil Science Society of America, 1982. p. 539-579.

PETRUZZELLI, G.; GUIDI, G.; LUBRANO, L. Ionic strength effect on heavy metal adsorption by soil. Communications in Soil Science and Plant Analysis, New York, v. 16, n. 9, p. 971-986, ago. 1985.
ROSS, S. M. Retention, transformation and mobility of toxic metals in soils. In: ROSS, S. M. (Ed.). Toxic metals in soil-plant systems. Chichester: John Wiley, 1994. p. 63-152.

SILVA JUNIOR, C. A.; BOECHAT, C. L.; CARVALHO, L. A. Atributos químicos do solo sob conversão de floresta Amazônica para diferentes sistemas na Região Norte do Pará. Brasil. Bioscience Journal, Uberlândia, v. 28, n. 4, p. 566-572, 2012.

SILVA, S. P. da; SILVA, D. A. S.; RUIVO, M. de L. P.; VIÉGAS, I. de J. M.; SILVA, R. L. da; ARAÚJO JÚNIOR, V. de A.; CONCEIÇÃO, H. E. da. Diversidade e comunidade microbiana em solos de terra preta nova em Tailândia-Pará, Brasil. Semina: Ciências Agrárias, Londrina, v. 34, n. 6, p. 3245-3256, 2013. Suplemento 1.

SINGH, B. R.; STEINNES, E. Soil and water contamination by heavy metals. In: LAI, R.; STEWART, B. A. (Ed.). Advances in soil science: soil process and water quality. Ankeny: Lewis, 1994. p. 233-237.

SOIL SURVEY STAFF. Soil Taxonomy: a basic system of soil classification for making and interpreting soil surveys. $12^{\text {nd }}$ ed. Washington DC: USDA-Natural Resources Conservation Service, 1999. 882 p.

SPARKS, D. L. Environmental soil chemistry. $2^{\text {th }}$ ed. San Diego: Academic Press, 2002. 353 p.

STEVENSON, F. Humus chemistry: genesis, composition, and reactions. $2^{\text {th }}$ ed. New York: John Wiley \& Sons, 1994. $496 \mathrm{p}$.

VIOLANTE, A.; COZZOLINO, V.; PERELOMOV, L.; CAPORALE, A. G.; PIGNA, M. Mobility and bioavailability of heavy metals and metalloids in soil environments. Journal of soil Science and plant nutrition, Temuco, v. 10, n. 3, p. 268-292, 2010. 